Journal of

Women's Health and Gynecology

\title{
Evaluation of Birth Trauma Associated with Locomotor System Injury
}

\section{Mehmet Sabri Balık ${ }^{1, *}$, Gülşah Balık ${ }^{2}$}

${ }^{1}$ Department of Orthopedics and Traumatology, Recep Tayyip Erdogan University School of Medicine, Rize, Turkey ${ }^{2}$ Department of Obstetrics and Gynecology, Recep Tayyip Erdogan University School of Medicine, Rize, Turkey

*Corresponding author: Mehmet Sabri Balık, Assistan Prof., Department of Orthopaedic and Traumatology, Recep Tayyip ErdoganUniversity School of Medicine, Rize, Turkey, Tel: 904-642-123-009; E-mail: sabribalik@gmail.com

Received Date: August 13, 2018; Accepted Date: September 17, 2018; Published Date: September 21, 2018

Citation: Mehmet Sabri Balık (2018) The Evaluation of Birth Injuries. J Womens Health Gyn 5: 1-6.

\section{Introduction}

Birth injury is described as a physical damage to the newborn due to mechanical influences during labor. Birth injury is reported in the frequency of $0.67-1.4 \%$ [1]. The birth injury is a major cause of neonatal mortality all over the world. Birth injury or obstetrical injuries are associated with different etiological causes. Risk factors of birth injury include three groups; maternal factors, neonatal factors and delivery factors. Maternal factors include maternal weight and pelvic abnormalities. Neonatal factors are fetal weight, fetal presentation anomalies and multiple pregnancy. Delivery factors are preterm delivery, prolonged or fastlabor and obstetric instrumentation during delivery (forceps and vacuum application) [2]. Birth injuries may also occur spontaneously without definable risk factors.

Birth injury can be classified in 3 groups as: 1- soft tissue damage (cephal haematoma, ecchymosis, caput suksadenium), 2nerve tissue damage (brachial plexus, facial nerve palsy and cranial nerve damage), 3-bone tissue injury (clavicle, femur, humerus and skull fracture) [3]. Birth injuries are often seen in the form of soft tissue injuries, while the peripheral-cranial nerve injuries and bone fractures rarely occur.

Bone tissue injury includes clavicle, femur and humerus in delivery. Long bone fractures are seen in the rate of 0.67 4 per 1000 live births $[1,4]$. Clavicular fracture is the most commonly reported trauma and its rate is of 2-3.5per 1000 live births. Femoral fracture rate is 0.13 per 1000 live births and it is much less common than humerus fractures [5,6,7]. Bone tissue injury and nerve damages can be seen together or separately. Clavicular fractures are occasionally responsible for lesions of the brachial plexus paralysis (BPP). The

(C)2018 The Authors. Published by the JScholar under the terms of the Creative Commons Attribution License http://creativecommons.org/licenses/by/3.0/, which permits unrestricted use, provided the original author and source are credited. incidence of birth-related injury significantly decreased today due to close monitoring of high-risk pregnancy and reduced application of high forceps. Birth injuries can be avoidable and inevitable. The incidence of birth trauma has decreased with advanced obstetric care and perinatal diagnosis (2). Although the incidence of birth trauma and related risk factors are known, birth injuries occur even in the absence of these risk factors in part of the births. In this study, we evaluated frequency of bone tissue injury and nerve tissue damage risk factors between the years 2011-2013 in our hospital

Keywords: birth injury, clavicule fracture, bone injuries, birth weight, shoulder dystocia, delivery type

\section{Materials and Methods}

This is a retrospective study which was carried out at a tertiary teaching hospital and 2491singleton full-term live births were evaluated for birth injuries between January 2011 and September 2013. Ethics committee approval was received from the local ethics committee (Approval number: 2018/177). In the study, only mechanical means of developing physical birth trauma was evaluated. We assessed the frequency of birth injury such as humerus fracture, clavicular fracture, femur fracture and BPP.

The collected data included demographic specifics such as fetal sex, gestational age, parity, maternal age, birth weight, type of delivery, place of fracture. Neither vacuum extraction nor forceps have been used within these patients. Multiple pregnancies, fetus with major anomalies and breech presentation were excluded from the study. We evaluated the frequency of birth injuries.

Pediatric staff examined newborns in the delivery room at hospital. The diagnosis of birth injury was established by physical examination and confirmed radiologically. Expert orthopaedic consultation was asked when birth injuries were suspected clinically. 


\section{Statistically}

Statistical analysis was performed using the SPSS17.0 package (SPSS, Chicago, IL). Comparisons were made between groups using Mann- Whitney U and Ki- Square tests, with a p value < 0.05 which was considered significant.

\section{Results}

The mean gestational age and the maternal age of the all groups were $38.46 \pm 1.978$ weeks and $29.09 \pm 5.81(16-48)$ years. The mean birth weight of the infants was $3218 \pm 586 \mathrm{gr}$ (range 1200-5500 g). There were a total of 2491 deliveries (1300 vaginal vertex deliveries and 1191 cesarean section) and 1226 (49.2\%) of them were girls and 1265 (50.8\%) of them were boys. Statistically significant association was observed between two groups on delivery type, parity and maternal age. Birth weight was higher in fracture group as compared to nonfracture group $(p=0.002)$.The comparison of the maternal and fetal characteristics of the newborns was shown at (Table1).

We identified 29 cases of birth injury (femur fracture, clavicle fracture, humerus fracture and BPP) with a prevalence of ( 29/2491) $1.03 \%$. The prevalence of the injuries were as follows; clavicular fractures (17 cases, 6.8 per 1000 live births), humerus fractures ( 2 cases, 0.8 per 1000 live births), femur fractures ( 2 cases, 0.8 per 1000 live births) and cases of BPP (7 cases, 2.7 per 1000 live births) and both clavicle fracture and BPP (1 case, 0.4 per 1000 live births).General features of the cases were shown at (Table 2).

\section{Discussion}

Birth injury is still inevitable and very real obstetric issue. It can be mild and transitory with a good outcome, but also tragic and devastating event, drastically altering the course of the child's life forever. Apart from perinatological significance, which comes from its influence on perinatal mortality and morbidity, birth injury is very important from medico-legal aspects. All obstetric interventions are at some degree risky and there are no absolutely accurate solutions.

Birth injury is reported in the frequency of 6.7-14 per 1000 live births [1]. Today, the incidence of birth traumas has been decreasing [3]. In our country, the frequency of birth trauma has been reported such as in varying proportions $0.22-5.2 \%$ in various studies $[9,10]$. In our study, birth trauma rate was found to be 7 per 1000 live births a 2-year period in our hospital. Clinical symptoms depend on the type, intensity and the grade of the birth injury. Local physical changes are most common of clinical manifestations. The diagnostic methods of birth injuries include clinical evaluation and observation, ultrasound and radiographic examination [8].
Risk factors of birth injury include maternal weight, pelvic abnormalities, fetal weight, fetal presentation anomalies, preterm delivery, prolonged or fast labor and obstetric instrumentation during delivery. Although birth injuries are often associated with traumatic birth, they rarely occur during normal spontaneous birth in the absence of any risk factor [2]. Other risk factor is maternal age. In the present study, we have shown that as maternal age increases, the rate of birth injuries increases as in literature [11]. One other risk factor is birth weight [12]. In our cases, mean birth weight was 3598 gr and increased birth weight raised the risk of birth injury. However, birth weight has not been found a predictor for perinatal fracture. The cut-off border of birth weight could not be determined.

Gender of the fetus seems as a risk factor. Male children are more affected from birth injury. The study of Levine et al. demonstrated that birth injuries affect male gender more than female gender [1]. In our study, we found that there was more male gender than female gender. Statistically significant association was not observed in fetal gender. Multiparity is known as a risk for the development of BPP and clavicle fracture [13]. In our study, most traumatic cases were multipare and as parity increased, the risk enhanced. This is because the previous delivery of multipare mothers was through vaginal way and smooth. This leads to the smooth delivery expectation of these mothers. Even health carers feel like this. However, this causes the negligence of risk evaluation. This condition contributes to the formation of injury. The applied vacuum and forceps along with macrosomia are the most important predisposing factors for birth injury. Application of forceps or vacuum extraction increases the incidence of birth injuries slightly. The risk rate increases when both vacuum and forceps are used together significantly [14]. Neither vacum nor forceps were used within studied groups.

Fetal birth injuries are relatively less common in caesarian sections as compared to vaginal deliveries. Skin lacerations are most common fetal birth injuries in cesareans deliveries. Although birth traumas are most often connected with vaginal deliveries, children delivered by cesarean section are not totally protected from those. Approximately, the rate was twice more in vaginal birth than in cesarean deliveries [15]. While the head trauma decreases in cesarean deliveries, the risk of long bone fractures continues. Long bone fractures are generally related to urgent cesarean operations [16, 17]. In our findings, there were two femur fractures, one was vaginal delivery, and the other was cesarean delivery.

Fracture of the clavicle is the most common birth injury and 


\begin{tabular}{|c|c|c|c|c|}
\hline & & Non injuries birth n (\%) & Fetal birth injuries n (\%) & Pvalue \\
\hline \multirow[b]{2}{*}{ Delivery type } & $\begin{array}{l}\text { Vaginal } \\
\text { Birth }\end{array}$ & $1273(97.9)$ & $27(2.1)$ & \multirow[b]{2}{*}{0.00} \\
\hline & $\mathrm{C} / \mathrm{S}$ & $1189(99.8)$ & $2(0.2)$ & \\
\hline \multirow[b]{2}{*}{ Parity } & Primipar & $770(99.5)$ & $4(0.5)$ & \multirow[b]{2}{*}{0.043} \\
\hline & Multipar & $1692(98.5)$ & $25(1.5)$ & \\
\hline \multicolumn{2}{|l|}{ Birth weight (g) } & $3314.9 \pm 486$ & $3598.6 \pm 411.6$ & 0.002 \\
\hline \multicolumn{2}{|l|}{ Gestationale age (weeks) } & $38.98+1.02$ & $39.24 \pm 0.63$ & 0.236 \\
\hline \multicolumn{2}{|l|}{ Maternal age } & $29.41 \pm 5.86$ & $31.48 \pm 4.71$ & 0.034 \\
\hline & Male & $1211(98.9)$ & $15(1.2)$ & \multirow[b]{2}{*}{0.786} \\
\hline Sex of the newborn & Female & $1251(98.9)$ & $14(1.1)$ & \\
\hline
\end{tabular}

Table 1: The comparison of the maternal and fetal characteristics

\begin{tabular}{|c|c|c|c|c|c|c|}
\hline & & $\begin{array}{l}\text { Femur fracture } \\
(\mathrm{n}=2)\end{array}$ & $\operatorname{BPP}(n=7)$ & $\begin{array}{l}\text { Clavicule } \\
\text { fracture }(n=17)\end{array}$ & $\begin{array}{l}\text { Humerus } \\
\text { Fracture }(n=2)\end{array}$ & $\begin{array}{l}\text { Claviculefracture+ } \\
\operatorname{BPP}(n=1)\end{array}$ \\
\hline \multirow{2}{*}{$\begin{array}{l}\text { Delivery } \\
\text { type (n) }\end{array}$} & $\begin{array}{l}\text { Vaginal } \\
\text { birth }\end{array}$ & 1 & 7 & 16 & 2 & \\
\hline & $\mathrm{C} / \mathrm{S}$ & 1 & 0 & 1 & 0 & 0 \\
\hline \multirow[b]{2}{*}{ Parity } & Primipar & 0 & 1 & 3 & 0 & 0 \\
\hline & Multipar & 2 & 6 & 14 & 2 & 1 \\
\hline \multicolumn{2}{|c|}{ Birth weight (g) } & $3.450 \pm 0.07$ & $3.580 \pm 0.49$ & $3.570 \pm 0.311$ & $3.550 \pm 0.91$ & 4500 \\
\hline \multicolumn{2}{|c|}{$\begin{array}{l}\text { Gestationale age } \\
\text { (weeks) }\end{array}$} & $39.5 \pm 0.70$ & $39.43 \pm 0.53$ & $39.06 \pm 0.65$ & $39.5 \pm 0.70$ & 40 \\
\hline \multicolumn{2}{|c|}{ Maternal age (years) } & $30.5 \pm 2.12$ & $31.86 \pm 5.46$ & $31.29 \pm 5.03$ & $31 \pm 4.24$ & 35 \\
\hline
\end{tabular}

Table 2: General features of the newborns with birth injuries

it occurs in nearly 0.5 - $1 \%$ of vaginal deliveries [18]. In the present study, the rate was $0.75 \%$ (17 neonate baby) and was the most common injury type. In one baby, BPP was observed simultaneously. In this case, the second delivery was a vaginal delivery and the birth weight was 4500 gr. Clavicular fracture is reported as inevitable complication of normal delivery and it is a mild birth trauma. Late sequela usually does not occur. The baby cannot move its painful, injured arm. A chest x-ray shows whether there is a broken bone or not. Ultrasound can be used as an alternative to radiographs with good sensitivity. Full recovery occurs without treatment. Less commonly there may be accompanying injuries to the brachial plexus paralysis, spine or humerus. The study of Peleg et al. found that neonatal clavicular fracture rate was $2.03 \%$. There was a relationship between birth weight and clavicular fracture [6]. In another study clavicle fracture rate was $0.5 \%$. They found that birth weight and advanced maternal age are associated with fracture of the clavicle [19]. Risk factors are shoulder dystocia, birth weigh, gestationale age. Sometimes clavicle fractures are not easy to identify. Most newborn infants with fractures have no symptoms and for that reason it is necessary to make repeated examinations for minimal physical findings during the first days of life. Displaced clavicle fractures are relatively easy although minimally displaced fracture may be evident only after the formation of callus. Thus, all neonatal are subject to radiography, ultrasound examination, multiple physical examination [20]. The clavicular spongy mass sign is a very important indicator for diagnosing neonatal clavicular fractures [21].

Fracture of humerus is a rare injury in delivery. A humerus fracture at birth varies between 0.1 and 0.2 fractures per 1000 live births [17]. The incidence of humerus fracture in the present study was 0.8 per 1000 live births. There were two babies with humerus fracture and their delivery type 
was vaginal. There are risks for humerus fracture in delivery in both vaginal and abdominal. Birth injuries especially in humerus fractures are rare in caesarean sections as compared to vaginal deliveries. The length of the skin incision, delivery time, and the type of uterine incision are factors associated with fetal injury in cesarean delivery. There are several case reports about humeral fracture in vaginal delivery [22]. But, there are two reports of bilateral humerus fracture after $\mathrm{C} / \mathrm{S}$ delivery [23]. Ultrasound should be considered if humerus fracture is suspected in a newborn. The treatment of humerus fracture is soft immobilization.

Fracture of femur is considered as a rare condition in newborns and has been described as difficult deliveries. The proper prenatal care for pregnant women is crucial for the quick determination of risk factors for birth trauma. Risk factors include malpresentation, disease osteoporosis, breech presentations, low birth weight, macrosomic baby and difficult or precipitous delivery. Femoral fractures should be cared, especially in difficult caesarean sections. Other causes may include poor relaxation, poor delivery techniques and small incision. The differential diagnosis of femoral fracture in a newborn includes osteomyelitis, osteogenesis imperfecta, child abuse, and metabolic bone diseases. The reported incidence varies between 0.13 and 0.077 per 1,000 deliveries [24]. In our study, femur fracture was reported in two babies (0.8 per 1000 live birth). This result was found as in literature. The weights of both babies were the same and one of them was normal vaginal delivery and the other was caesarean delivery. If bone fracture is suspected, full clinical examination and proper orthopaedic consultation must be done. The treatment is strict immobilization of the femoral shaft. These fractures have very good prognosis.

BPP occurs as two different clinics such as Erb-Duchenne palsy (EDP) and Klumpke palsy (KP). EDP includes almost $80 \%$ of cases and affects nerve roots of C5-6. KP occurs less frequently and affects $\mathrm{C} 8$ - T1 nerve roots. The incidence of lesions of the brachial plexus due to clavicular fractures is very low. The frequency of BPP is 0.4-4.6 per 1000 live births [8]. Demonstrated that the incidence is believed to range from 0.35 to 5 cases per 1000 live births [25]. In the present study, the rate was 0.1 per 1000 live births. The number of babies with BPP was 7 and there was one baby with bone fracture together with BPP. All cases were EDP and vaginal delivery. Birth weights were between 3000-4000 gr. The baby that was both BPP and clavicle fracture was born $4500 \mathrm{gr}$. If the baby shoulder is not active during abduction and external rotation of the shoulder, Erb's palsy is diagnosed. Moro reflex cannot be seen, but normal active movement of the fingers and wrist can be made. When Erb's palsy or other brachial plexus injury is suspected, $\mathrm{X}$-ray films are not required. Prognosis is uncertain in the first four weeks. The risk factors include maternal diabetes mellitus, maternal obesity, maternal excessive weight gain, multiparite, fetal macrosomia, shoulder dystosia; prolonged second stage of labor [5].Any risk factor cannot be detected in $25 \%$ of cases with brachial plexus injury [6]. Cesarean section has a lower association than vaginal delivery risk for BPP. In these cases, during the $\mathrm{C} / \mathrm{S}$, shorter segmental transverse incision of the uterus could be insufficient and small vertical incision may be needed [26]. Birth weight was showed as a significant risk factor regardless of delivery method for BPP [27]. Routine cesarean delivery for suspected macrosomia is difficult to be recommended and cesarean section cannot totally eliminate the risk. Critical question: Can it be possible to predict birth weight for BPP? There are not antenatal fetal weight values for predicting it yet. There is no absolutely certain way to prevent BPP. Although the risk factors associated with BPP are known, the neonates who will experience BPP cannot be predicted. If any infant cannot recover, BPP is not considered as a result of medical negligence. Further studies are needed to prevent injury. This high incidence suggests that issues still remain relevant.

The simple answer for what we should do is to avoid from possible risks and diagnose the injury early. How can we manage birth injuries after making a diagnosis? Almost all the consequences could be reduced by professional and careful treatment. Neonate should be referred to a centre with special expertise in managing BPP. These children get the care advantage of specialized multidisciplinary teams for potential therapies. It is clearly stated in the literature that there is a direct correlation between birth weight and birth trauma. A birth weight of $\geq 4000 \mathrm{~g}$ is a known risk factor for birth trauma (28).

\section{Conclusion}

The risk of physical birth injury should be noted in all deliveries. To prevent birth trauma and reduce its frequency; timely C / S practice, appropriate obstetric care methods and related factors must be identified. We strongly recommend a very close cooperation between obstetricians/ perinatologists, neonatologists, pediatricians, surgeons, and other specialists that are involved in treatment of injured neonates. 


\section{References}

1) Levine MG, Holrody J, Woods JR et al. (1984) Birth trauma: Incidence and predisposing factors. ObstetGynecol 63:792-5.

2) Perlow JH, Wigton T, Hart J, Strassner HT, Nageotte MP, et al. (1996) Birth trauma. A five-year review of incidence and associated perinatal factors. J Reprod Med. 41:754-60.

3) Petroviç O and Biliç I. (2008) bırth trauma - obstetrıc view. Gynaecol Perinatol 17:68-72.

4) Al-Habdan I: Birth-related fractures of long bones. (2003) Indian J Pediatr 70: 959-960.

5) Lam MH, Wong GY, Lao TT. (2002) Reappraisal of neonatal clavicular fracture. Relationship between infant size and risk factors. J Reprod Med 100: 115

6) Peleg D, Hasnin J, Shalev E. (1997) Fractured clavicle and Erb's palsy unrelated to birth trauma. Am J Obstet Gynecol 177:1038-1040.

7) Morris S, Cassidy N, Stephens M, McCormack D, McManus F. (2002) Birth associated femoral fractures: incidence and outcome. J Pediatr Orthop 22:27-30.

8) Backe B, Magnussen EB, Johansen OJ, Sellaeg G, Russwurm H. (2008) Obstetric brachial plexus palsy: a birth injury not explained by the known risk factors. Acta Obstet Gynecol Scand 87:1027-32.

9) Bülbül A, Okan F, Nuhoğlu A. (2006) Birth Associated Physical Traumas of the Newborn. Haseki Tip Bülteni 9:4

10) Tütüncüler F, Altıay S, Gaffaroğlu C, Acunaş B: (2004) Travmatik Doğum Vakalarının Değerlendirilmesi. Çocuk Dergisi 4:216-220.

11) Murguía-González A, Hernández-Herrera R, NavaBermea M. 2013 [Risk factors of birth obstetric trauma]. Ginecol Obstet Mex 81:297-303.

12) Gudmundsson S, Henningsson AC, Lindqvist $P$. (2005) Correlation of birth injury with maternal height and birthweight. BJOG 112:764

13) Piatt JH. (2004) Birth injuries of Brachial plexus. Pediatr Clin N Am.421-440

14) Demissie K, Rhoads GG, Smulian JC, Balasubramanian BA, Gandhi K, et al. (2004) Operative vaginal delivery and neonatal and infant adverse outcomes: population based retrospective analysis. BMJ 329:24-29.

15) Signore C, Klebanoff M. (2008) Neonatal Morbidity and Mortality After Elective Cesarean Delivery. Clin Perinatol 35: 361-vi.
16) Canpolat FE, Köse A, Yurdakök M. (2010) Bilateral humerus fracture in a neonate after cesarean delivery.Arch Gynecol Obstet. 281:967-969.

17) Basha A, Amarin Z, Abu-Hassan F. (2013) Birthassociated long-bone fractures. Int J Gynaecol Obstet. 123:127130.

18) Mavrogenis AF, Mitsiokapa EA, Kanellopoulos AD, Ruggieri P, Papagelopoulos PJ. (2011) Birth fracture of the clavicle. Adv Neonatal Care 11:328-331.

19) Kaplan B, Rabinerson D, Avrech OM, Carmi N, Steinberg DM, et al. (1998) Fracture of the clavicle in the newborn following normal labor and delivery. Int J Gynaecol Obstet 63:15-20.

20) Beall MH, Ross MG. (2001) Clavicle fracture in labor: risk factors and associated morbidities. J Perinatol 21:513-515

21) Reiners $\mathrm{CH}$, Souid AK, Oliphant $\mathrm{M}$, Newman N. (2000) Palpable spongy mass over the clavicle, an under utilized sign of clavicular fracture in the newborn. Clin Pediatr (Phila) 39:695-698.

22) Canpolat FE, Köse A, Yurdakök M. (2010) Bilateral humerus fracture in a neonate after cesarean delivery.Arch Gynecol Obstet 281:967-969.

23) Dias E. (2012) Bilateral humerus fracture following birth trauma. J Clin Neonatol 1:44-45.

24) Morris S, Cassidy N, Stephens M, McCormack D, McManus F. (2002) Birth associated femoral fractures: incidence and outcome. J Pediatr Orthop 22:27-30.

25) McFarland LV, Raskin M, Daling JR, Benedetti TJ. (1986) Erb/Duchenne's palsy: A consequence of fetal macrosomia and method of delivery. Obstet Gynecol 68:784788.

26) Alexander, Leveno, K. J, Hauth, Landon, et al. (2006) Fetal injury associated with cesarean delivery. Obstetrics \&Gynecology 108:885-890.

27) Ouzounian JG, Korst LM, Miller DA, Lee RH. (2013) Brachial plexus palsy and shoulder dystocia: obstetric risk factors remain elusive. KAm J Perinatol. 30:303-307.

28) Linder I, Melamed N, Kogan A, Merlob P, Yogev Y, et al. (2012) Gender and birth trauma in full-term infants. The Journal of Maternal-Fetal \& Neonatal Medicine 25:1603-1605. 
Submit your manuscript to a JScholar journal and benefit from:

- Convenient online submission

- Rigorous peer review

- Immediate publication on acceptance

- Open access: articles freely available online

9. High visibility within the field

g Better discount for your subsequent articles Submit your manuscript at http://www.jscholaronline.org/submit-manuscript.php 